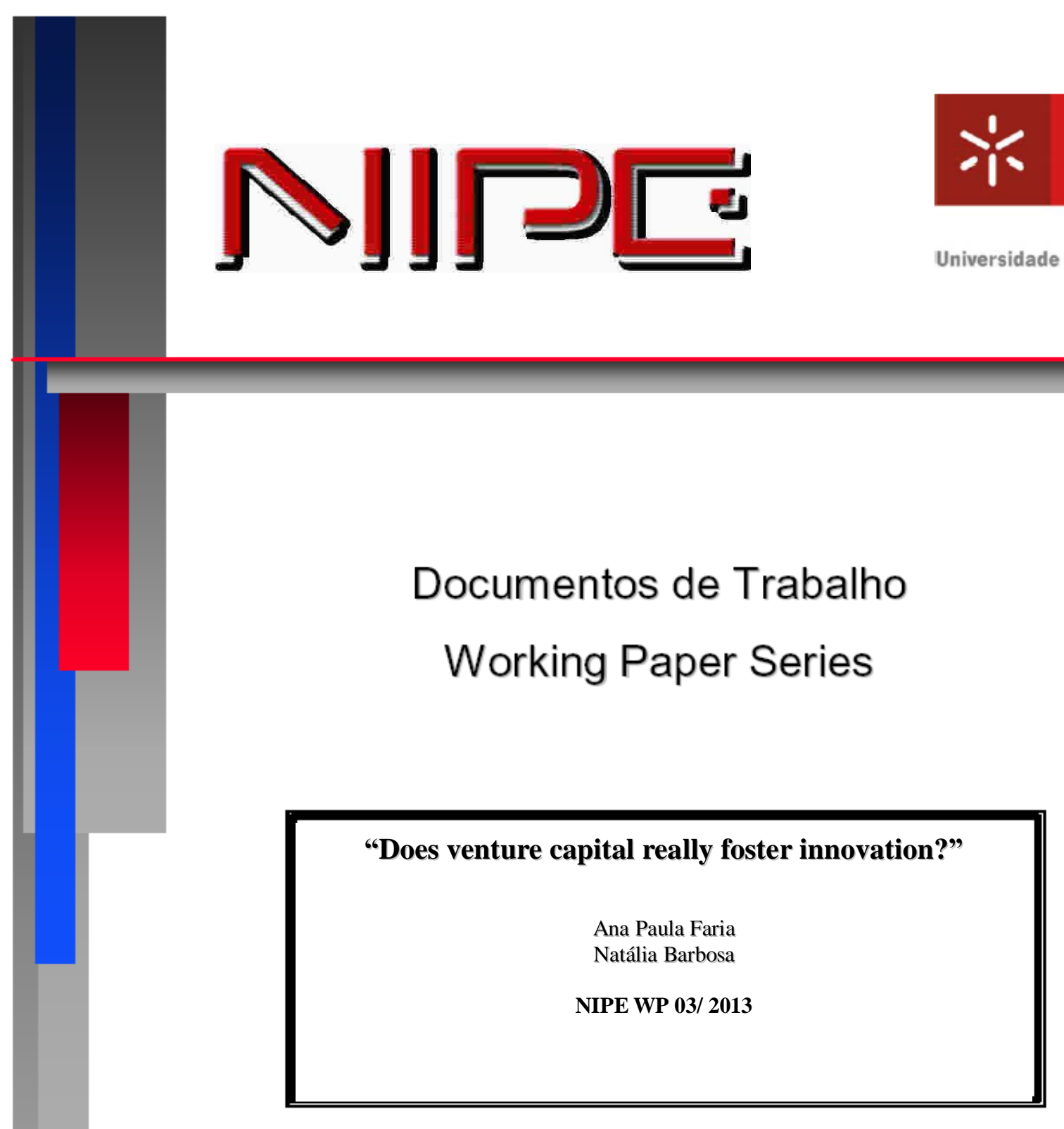

NÚCLEO DE INVESTIGAÇÃO EM POLÍTICAS ECONÓMICAS UNIVERSIDADE DO MINHO 


\section{"Does venture capital really foster innovation?"}

Ana Paula Faria

Natália Barbosa

NIPE* WP 03/ 2013

URL:

http://www.eeg.uminho.pt/economia/nipe



\title{
Does venture capital really foster innovation?
}

\author{
Ana Paula Faria* \\ Economic Policies Research Unit (NIPE) \\ Department of Economics, School of Economics and Management, University of \\ Minho, \\ 4710-057 Braga, Portugal \\ Phone: +(351) 253604245 \\ Email: apfaria@eeg.uminho.pt \\ * Corresponding author \\ Natália Barbosa \\ Economic Policies Research Unit (NIPE) \\ Department of Economics, School of Economics and Management, University of \\ Minho, \\ 4710-057 Braga, Portugal \\ Phone: +(351) 253604535 \\ Email: natbar@eeg.uminho.pt
}

\begin{abstract}
Using panel data of 17 European Union countries, we find robust empirical support for a positive impact of venture capital on innovation. After controlling for the potential endogenous relationship between venture capital and innovation, the results indicate that venture capital fosters innovation but mainly on a later stage.
\end{abstract}

Keywords: venture capital; innovation; dynamic panel data

JEL: O31; G30 


\section{Introduction}

The role of venture capital (VC) in promoting innovation has received growing attention recently by both academics and policy makers. It has been argued that VC is particularly well suited to support the creation of innovative startup firms. Frequently these new firms own innovative technologies but they lack financial resources as well as expertise in terms of knowledge of markets and entrepreneurial. For this reason governments of European countries have been concerned in fostering $\mathrm{VC}$ as a means to achieve job creation, innovation and economic growth (Bottazi and Da Rin, 2002).

However, the real effects of $\mathrm{VC}$ on innovation have been difficult to establish (Hall and Lerner, 2010; Dessi and Yin, 2012). This is largely due to the causality relationship between VC and innovation. On one hand, VC is aimed at supporting innovation. On the other hand, there could be more innovation not because VC caused it, but rather because venture capitalists reacted to the signaling made by firms. In this case, the more innovative firms select venture capitalists for financing rather than VC causing firms to be more innovative. Hence in order to assess the true impact of VC on innovation this issue needs to be taken into account.

So far, few studies have dealt with the potential endogenous relationship (Popov and Rossenboom, 2012; Bertoni et al., 2011; Samila and Sorenson, 2011). However, most of these studies do not consider the dynamic nature of the data that typically characterizes innovation and, specifically, patents counts. As such, failing to do so will produce biased. Bertoni et al. (2011) and Samila and Sorenson (2011) studies are the exception yet they do not investigate the impact of $\mathrm{VC}$ on innovation per se but rather on the number of firm start-ups or firm performance.

This paper fills this gap by estimating a dynamic panel data model for 17 European countries observed during 2000-2009 that allows us to control for the potential endogenous relationship between VC and innovation as well as to take into account the dynamic characteristic of our dependent variable. Our paper is close to Geronikolau and Papachistou (2012) and Popov and Roosenboom (2012) in that we also use European country-level data.

\section{Data and methodology}

We use annual VC data obtained from EUROSTAT statistics database. The observed countries are Belgium, Czech Republic, Denmark, Finland, France, Germany, Greece, Hungary, Ireland, Italy, Netherlands, Norway, Poland, Portugal, Spain, Sweden and United 
Kingdom. Patent data refer to the European Patent Office (EPO) and was collected from the EUROSTAT database.

Following previous contributions (Hirukawa and Ueda, 2011; Geronikolau and Papachristou, 2012) we choose patent applications rather than patent grants. The former are considered a good proxy to innovative ideas, whereas patent grant is a better proxy to innovative output (Hall and Lerner, 2010). In this sense, the signalling effect of a patent is more pronounced on the time of application rather than on the time of patent grant, which seems more adequate to study the relationship between $\mathrm{VC}$ and innovation. Another reason justifying the use of patent applications is because there might be a significant time lag between filing and application and receiving a grant. From the EUROSTAT we also obtained for each country data on business and government research and development (R\&D) expenditures, the ratio of science and technology labour to total labour force, total aggregate investment and gross domestic product (GDP). From the Economic Freedom of the World (EFW) we collected an index of protection of intellectual property that ranges from 1 (low) to 10 (high) protection level.

Our main goal is to test for the impact of VC investments on innovation. Thus, country $i$ 's patents application function can be described as:

Patents $_{i t}=\beta_{1}$ Patents $_{i t-1}+\beta_{2} \mathrm{VC}_{i t}+\beta_{3} \mathrm{X}_{i t}+\varepsilon_{i t}$

where Patents ${ }_{i t}$ is country $i$ 's patent applications ratio to country $i$ gross domestic product (GDP) in year $t$, Patents ${ }_{i t-l}$ is its lagged value, $\mathrm{VC}_{i t}$ is country $i$ 's investments in venture capital, measured by the ratio of total investments in venture capital to aggregate investment, $\mathrm{X}_{i t}$ is a vector of control variables that are expected to influence country i's patent applications and not $\mathrm{VC}$, and $\varepsilon_{i t}$ is an error term.

The inclusion in all models of the lagged dependent variable as one of the covariates and the potential endogenous nature of the relationship between VC investments and patents require the use of appropriate estimation techniques. If causality between VC investments and patents runs in both directions then $\mathrm{VC}_{i t}$ is endogenous in model (1) and correlated with the contemporaneous error term. An additional concern is the dynamic nature of (1), which gives rise to autocorrelation and Patents $s_{i-1}$ will be correlated with the country-specific unobserved individual effect.

To address these issues we follow the contributions by Arellano and Bond (1991), Arellano and Bover (1995) and Blundell and Bond (1998) on dynamic panel-data models. The autocorrelation problem can be eliminated by taking first-differences of equation (1) to eliminate country-specific unobserved individual effects and use as instruments for $\Delta$ Patents $_{i t \text { - }}$ ${ }_{1}$, lagged levels of the dependent variable from two or more periods before, which are not 
correlated with the residuals in differences, assuming no serial correlation in $\varepsilon_{i t}$. The VC variable, being endogenous, can be instrumented in a similar way. The validity of the instruments used in the estimations can be checked using the Sargan test for overidentifying restrictions. As additional exogenous instruments we include a measure of bank concentration, which is the ratio of total assets of the three largest comercial banks to total assets of all comercial banks, the corporate tax rate and an index of trust by citizians in European institutions. These data were collected from the EUROBAROMETER. Descriptive statistics for the relevant variables are presented in Table 1.

\section{Insert Table 1 here}

\section{Empirical Results}

Table 2 presents estimates for the patents applications function by the System Generalized Method of Moments (GMM-SYS). For comparison purposes we also present estimates of equation (1) by pooled OLS. Although OLS estimates, column (1), produce biased estimates, they show a strong degree of persistence in patents applications as expected, and a nonsignificant coefficient on VC investments. For the GMM-SYS we use the one-step estimation with finite-sample correction for standard errors suggested by Windmeijer (2005). We instrument for the differenced equations, first-differences of the dependent variable using its levels lagged at least three periods, and its lagged first-differences as instruments for the level equations. VC investments are treated as endogenous and instrumented similarly to lagged patents. In order to limit the number of instruments we also apply a single moment condition for each period and regressor in columns (2) through (4).

\section{Insert Table 2 here}

Focusing on our key variable we can see from column (2) that VC investments are statistically significant. The tests for serial correlation in the error term reveal a significant AR1 and insignificant AR2. This result constitutes a first validation of the instruments used, which is then confirmed by the significant Sargan test of overidentifying restrictions. As expected the estimated coefficient of the lagged variable is smaller in GMM-SYS than in OLS. Columns (3) and (4) show the impact of early-stage VC and late-stage VC respectively. Interestingly, the estimates show that only late-stage $\mathrm{VC}$ has a significant impact on innovation. This result suggests that venture capitalists are more willing to support innovation only after the initial and more uncertain stage of technology development has been overcome.

\section{Conclusion}


This research extends our understanding of the impact of VC investments on innovation at the country level. By explicitly addressing the potential endogenous relationship between VC and innovation and controlling for persistence in the patents series our results show that patents applications are in fact influenced by VC venturing. However, as one discriminates the effect of $\mathrm{VC}$ by its type or stage, results show that only the later-stage $\mathrm{VC}$ capital is promoting innovation. Hence, this result is consistent with the view that the VC role is more to help the commercialization of innovation rather than to foster its creation. These results provide policy makers a clear picture of the true impact of $\mathrm{VC}$ on innovation and what and not expect from venture capitalists regarding their role in supporting innovation.

\section{Acknowledgements:}

The authors acknowledge the research grant form the Portuguese Science Foundation PTDC/EGE-ECO/098295/2008.

\section{References}

Arellano, M. and Bond, S. (1991). "Some tests of specification for panel data: Monte Carlo evidence and application to employment equation", Review of Economic Studies, 58, 277-297. Arellano, M. and Bover, O. (1995). "Another look at the instrumental variable estimation of error-components models", Journal of Econometrics, 68, 29-52.

Blundell, R. and Bond, S. (1998). "Initial conditions and moment restrictions in dynamic panel data models", Journal of Econometrics, 87, 115-143.

Bertoni, F., Colombo, M., Grilli, L. )2011). "Initial capital financing and the growth of hoightech start-ups: Disentangling treatment from selection effects”, Research Policy, 40, 10281043.

Bottazzi, L. and Da Rin, M. (2002). "Venture Capital in Europe and the Financing of Innovative Companies," Economic Policy, 17(34), 229-265.

Crépon, B. and Duguet, E. (1997). "Estimating the Innovation Function from Patent Numbers: GMM on Count Panel Data," Journal of Applied Econometrics, 12(3), 243-263.

Dessí, R. and Yin, N. (2012). "The Impact of Venture Capital on Innovation", The Impact of Venture Capital on Innovation, in D. Cumming (ed.) Oxford Handbook of Venture Capital, Oxford University Press (2012).

Geronikolau, G. and Papachistou, G. (2012), "Venture Capital and Innovation in Europe", Modern Economy, 3, 454-459. 
Hall, B. and Lerner, J. (2010). "The Financing of R\&D and Innovation", in B. Hall and N. Rosemberg (eds.) Handbook of the Economics of Innovation, Elsevier-North Holland.

Hirukawa, M. and Ueda, M. (2011). "Venture capital and innovation: which is first?", Pacific Economic Review, 16, 421-465

Popov, A. and Roosenboom, P. (2012). "Venture capital and patented innovation: evidence from Europe”, Economic Policy, 27, 447-482.

Samila, S., and Sorenson, O., 2011. Venture capital, entrepreneurship and economic growth. Review of Economics and Statistics, 93(1), 338-349.

Windmeijer, F. (2005). "A finite sample correction for the variance of linear two-step GMM estimators", Journal of Econometrics, 126(1), 25-51. 
Table 1: Empirical variables acronym, description, descriptive statistics and correlation matrix.

\begin{tabular}{|c|c|c|c|c|}
\hline \multicolumn{5}{|l|}{ Panel A } \\
\hline Variable & \multicolumn{3}{|c|}{ Description } & Obs \\
\hline Patents & \multicolumn{3}{|c|}{ Ratio of patents applications at the EPO to GDP } & 170 \\
\hline $\mathrm{VC}$ & \multicolumn{3}{|c|}{ Ratio of total venture capital investments to total investment } & 186 \\
\hline VC_early stage & \multicolumn{3}{|c|}{$\begin{array}{l}\text { Ratio of early stage venture capital investments to total } \\
\text { investment }\end{array}$} & 186 \\
\hline VC_late stage & \multicolumn{3}{|c|}{$\begin{array}{l}\text { Ratio of late stage venture capital investments to total } \\
\text { investment }\end{array}$} & 186 \\
\hline \multicolumn{5}{|l|}{ Panel B } \\
\hline & Patents & $\mathrm{VC}$ & VC_early stage & VC_late stage \\
\hline Patents & \multicolumn{3}{|l|}{1.000} & \\
\hline $\mathrm{VC}$ & 0.188 & 1.000 & & \\
\hline VC_early stage & 0.131 & 0.819 & 1.000 & \\
\hline VC_late stage & 0.192 & 0.971 & 0.658 & 1.000 \\
\hline
\end{tabular}


Table 2: Estimates of the impact of venture capital on innovation

\begin{tabular}{|c|c|c|c|c|}
\hline \multicolumn{5}{|l|}{ Dependent variable: Patents } \\
\hline Estimator & OLS & $\begin{array}{l}\text { GMM- } \\
\text { SYS }\end{array}$ & $\begin{array}{c}\text { GMM- } \\
\text { SYS }\end{array}$ & $\begin{array}{c}\text { GMM- } \\
\text { SYS }\end{array}$ \\
\hline & (1) & (2) & (3) & (4) \\
\hline Patents $_{i t-1}$ & $\begin{array}{c}0.929 * * * \\
(0.023)\end{array}$ & $\begin{array}{c}0.795 * * * \\
(0.093)\end{array}$ & $\begin{array}{c}0.897 * * * \\
(0.113)\end{array}$ & $\begin{array}{c}0.828 * * * \\
(0.097)\end{array}$ \\
\hline $\mathbf{V C}_{i t}$ & $\begin{array}{c}0.022 \\
(0.013)\end{array}$ & $\begin{array}{c}0.115 * * * \\
(0.044)\end{array}$ & - & - \\
\hline VC_early stage $_{i t}$ & - & - & $\begin{array}{c}0.004 \\
(0.030)\end{array}$ & - \\
\hline VC_later stage $_{i t}$ & - & - & - & $\begin{array}{c}0.127 * * \\
(0.054)\end{array}$ \\
\hline Observations & 135 & 115 & 115 & 115 \\
\hline Countries & 17 & 16 & 16 & 16 \\
\hline R-squared & 0.993 & - & - & - \\
\hline $\mathrm{AR}(1)$ & - & -4.41 & -4.07 & -4.36 \\
\hline (p-value) & - & $(0.000)$ & $(0.000)$ & $(0.000)$ \\
\hline $\operatorname{AR}(2)$ & - & 0.85 & 0.42 & 0.76 \\
\hline (p-value) & - & $(0.395)$ & $(0.676)$ & $(0.488)$ \\
\hline Sargan Test & - & 18.58 & 12.18 & 16.44 \\
\hline (p-value) & - & $(0.017)$ & $(0.143)$ & $(0.036)$ \\
\hline $\mathrm{DF}$ & - & 8 & 8 & 8 \\
\hline
\end{tabular}

Notes: GMM stands for GMM system estimation; GMM estimates based on a reduced set of instruments with moment conditions in the interval $t-3$ and $t-5$ for equations in diferences and between $\mathrm{t}-2$ for the equations in levels. All GMM estimates are based on the hypothesis of VC being endogenous and with finite sample correction proposed by Windmeijer (2005). Standard errors in parenthesis. Significance level for which the null hypothesis is rejected: ***1\%, **5\% and *10\%. All regressions include control variables and additional instruments as described in section 2 . 


\section{Most Recent Working Paper}

NIPE WP Faria, Ana Paula e Natália Barbosa, “Does venture capital really foster innovation?”, 2013

03/2013

NIPE WP Esteves, Rosa Branca, "Customer Poaching with Retention Strategies”, 2013

$02 / 2013$

NIPE WP Aguiar-Conraria, Luís, Teresa Maria Rodrigues e Maria Joana Soares, "Oil Shocks and the

01/2013 Euro as an Optimum Currency Area", 2013

NIPE WP Ricardo M. Sousa, "The Effects of Monetary Policy in a Small Open Economy: The Case of

27/2012 Portugal" 2012

NIPE WP Sushanta K. Mallick e Ricardo M. Sousa, "Is Technology Factor-Neutral? Evidence from the US

26/2012 Manufacturing Sector" 2012

NIPE WP Jawadi, F. e Ricardo M. Sousa, "Structural Breaks and Nonlinearity in US and UK Public Debt"

$25 / 2012 \quad 2012$

NIPE WP Jawadi, F. e Ricardo M. Sousa, "Consumption and Wealth in the US, the UK and the Euro Area:

24/2012 A Nonlinear Investigation" 2012

NIPE WP Jawadi, F. e Ricardo M. Sousa, “ Modelling Money Demand: Further Evidence from an

23/2012 International Comparison" 2012

NIPE WP Jawadi, F. e Ricardo M. Sousa, “Money Demand in the euro area, the US and the UK:

22/2012 Assessing the Role of Nonlinearity" 2012

NIPE WP Agnello, L, Sushanta K. Mallick e Ricardo M. Sousa, "Financial Reforms and Income

21/2012 Inequality" 2012

NIPE WP Agnello, L, Gilles Dufrénot e Ricardo M. Sousa, “Adjusting the U.S. Fiscal Policy for Asset

20/2012 Prices: Evidence from a TVP-MS Framework t" 2012

NIPE WP Agnello, L e Ricardo M. Sousa, "Fiscal Adjustments and Income Inequality: A First

19/2012 Assessment" 2012

NIPE WP Agnello, L, Vitor Castro e Ricardo M. Sousa, "Are there change-points in the likelihood of a

18/2012 fiscal consolidation ending?" 2012

NIPE WP Agnello, L, Vitor Castro e Ricardo M. Sousa, "What determines the duration of a fiscal

17/2012 consolidation program?" 2012

NIPE WP Veiga, Linda, "Voting functions in the EU-15", 2012

$16 / 2012$

NIPE WP Alexandre, Fernando e Pedro Bação, "Portugal before and after the European Union: Facts on

15/2012 Nontradables", 2012

NIPE WP Esteves, Rosa Branca e Carlo Reggiani, "Behaviour-Based Price Discrimination with Elastic

14/2012 Demand", 2012

NIPE WP Afonso, Oscar, Sara Monteiro, Maria Thompson “ Innovation Economy, Productive Public

13/2012 Expenditures and Economic Growth ", 2012

NIPE WP Esteves, Rosa Branca “Price Discrimination with Private and Imperfect Information”, 2012

$12 / 2012$

NIPE WP Castro, Vítor "Macroeconomic determinants of the credit risk in the banking system: The case of $11 / 2012$ the GIPSI", 2012

NIPE WP Bastos, Paulo, Natália Pimenta Monteiro e Odd Rune Straume "Privatization and corporate

10/2012 restructuring", 2012

NIPE WP Castro, Vítor e Rodrigo Martins "Is there duration dependence in Portuguese local

09/2012 governments' tenure?", 2012

NIPE WP Monteiro, Natália Pimenta e Geoff Stewart “ Scale, Scope and Survival: A Comparison of

08/2012 Labour-Managed, and Capitalist Modes of Production”, 2012

NIPE WP Aguiar - Conraria, Luís, Teresa Maria Rodrigues e Maria Joana Soares " Oil Shocks and the

07/2012 Euro as an Optimum Currency Area", 2012

NIPE WP Bastos, Paulo,Odd Rune Straume e Jaime A. Urrego "Rain, Food and Tariffs ”, 2012

06/2012

NIPE WP $\quad$ Brekke, Kurt R., Luigi Siciliani e Odd Rune Straume, “Can competition reduce quality?”, 2012 